
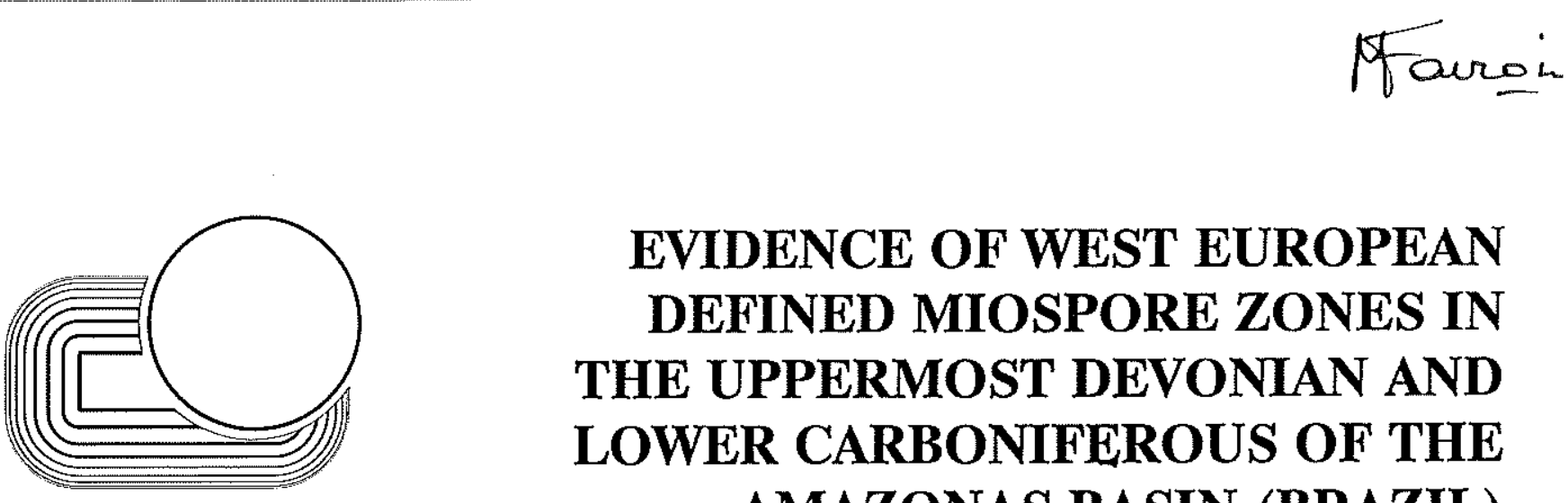

\title{
EVIDENCE OF WEST EUROPEAN DEFINED MIOSPORE ZONES IN THE UPPERMOST DEVONIAN AND LOWER CARBONIFEROUS OF THE AMAZONAS BASIN (BRAZIL)
}

STANISLAS LOBOZIAK

Laboratoire do Palébotanique, URA 1365 du CNRS, Université des Sciences et Teclniques de Lillo Flandres Artols, 59655 Villenetwe d'Ascq Cedex (Prance).

MAURICE STREEL

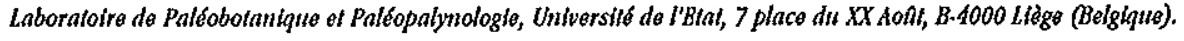

MARIO V. CAPUTO

Peirobras/Denor/Dinter, Rodowia Aribur Bermardes, 5511, 66000 Belem, PA (Brazil).

José HenRique G. DE MELO

Cenpes/Divex/Sebipe, CHA, Univ, Q.7, 1. Fundao, 21910 Rio de Janeiro, RJ (Brazil).

\section{ABSTRACT}

Uppermost Devonian and Lower Carboniferous miospore Zones previously defined in western Europe are identified in a borehole in the Amazonas Basin in Brazil. They range with some discontinuity from the uppermost Famennian to the lowermost Visean. Except for a few species which are listed, most of the taxa are common to Euramerica and Gondwana.

MISB BN ÉVIDBNCB DB ZONBS DB MIOSPORES DÉFINIES BN RUROPB OCCIDENTALB DANS LB DÉVONIBN TERMINAL BT LB CARBONIRÈRB INFÉRIBUR DU BASSIN DB L'AMAZONIB (BRÉSIL).

\section{RÉSUMÉ}

Des zones de miospores du Dévonien terminal et du Carbonifère inférieur, antérieurement définies en Europe occidentale, sont identifiées dans un sondage du bassin de l'Amazonie (Brésil). Elles se distribuent, avec quelques discontinuités, du Famennien terminal au Viséen basal. A l'exception de quelques espèces qui sont citées, la plupart des taxons sont communs à l'Euramérique et au Gondwana.

KEY-WORDS : MIOSPORES, LOWER CARBONIFEROUS, GONDWANA, BRAZIL. MOTS-CLÉS : MIOSPORES, CARBONIFËR INFÉRIEUR, GONDWANA, BRÉSIL. 


\section{INTRODUCTION}

The results presented below are originated from a miospore analysis of cores from the borehole 2-LF-1AM, drilled from May 1962 to March 1963 by Petrobras in the Amazonas Basin and they constitute a first contribution to a wider investigation of Devonian and Carboniferous miospore zonations in the Amazonas and Parnaiba Basins.

This first contribution intends to demonstrate the existence of well known West-European characteristic miospores in a region which belongs to Western Gondwana. It also displays some similary of the succession order of their first occurrences and therefore the possibility of stratigraphic correlations, particularly with the elaborated British Isles miospore zonations.

\section{BOREHOLE LOCALIZATION, LITHOSTRATIGRAPHY AND FORMER BIOSTRATIGRAPHY}

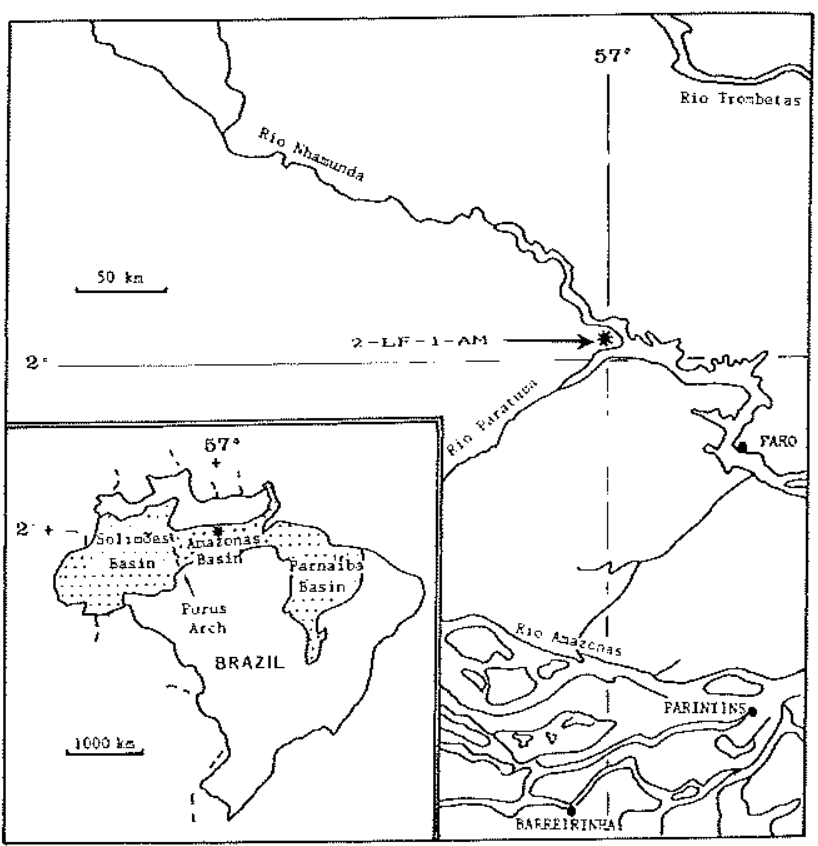

Figure 1 - Location of 2-LF-1-AM borehole.

Localisation du sondage $2 \cdot L P \cdot I-A M$.

The borehole 2-LF-1-AM was drilled in the Lago do Faro area, latitude $1^{\circ} 57^{\prime} 20^{\prime \prime} \mathrm{S}$, longitude $56^{\circ} 58^{\prime} 17^{\prime \prime} \mathrm{W}$ (fig. 1), in the central western part of the Amazonas Basin. Productive discrete samples are from depth intervals 2485,00/2483,80 $\mathrm{m}$ (core 55) and 2256,80/ $2149,70 \mathrm{~m}$ (cores 52,51 and 29 to 14), that include two distinct Paleozoic formations.
The lowermost stratigraphic unit covered by the sampling is the Oriximina Formation $(2615 / 2260 \mathrm{~m})$, core 55 being situated in its lower half. The Oriximiná Formation is composed of interbedded sandstones and shale layers, and attains maximum thickness (up to 430 $\mathrm{m})$ just in the region where borehole 2-LF-1-AM has been drilled. It corresponds to the uppermost division of the Curuá Group sensu Caputo 1984, and contains Daemon's 1974 biostratigraphic intervals VIII through XI. This Oriximiná Formation overlies conformably upper Devonian glaciogenic beds belonging to the $\mathrm{Cu}$ riri Formation (an intermediate division of the Curuá Group).

The remaining samples are all included in the Faro Formation (2260/2129 m), a sandy/shaly unit that rests conformably on the Curua Group and is unconformably overlain by sandstones of the Middle Carboniferous Monte Alegre Formation. It also displays maximum thickness (up to $330 \mathrm{~m}$ ) in the 2-LF-1-AM region, and comprises Daemon's biostratigraphic interval XII. The biostratigraphic intervals VIII to XII are correlated by Daemon 1974 with the late Famennian to Visean time interval (fig. 2).

\section{BIOSTRATIGRAPHIC RESULTS}

In the lowermost sample, miospores are rare, dark and damaged. They are more abundant and better preserved in other samples. Nevertheless, between 2231,60 and $2190,00 \mathrm{~m}$, samples are barren or, at best, have only poor assemblages of morphologically simple miospores without any stratigraphic significance.

Selected species are listed on fig. 2. They do not represent all the miospores observed but only the most significant ones for our purpose. The other miospores are morphologically simple forms including Apiculiretusispora and more elaborated, coarsely ornamented Convolutispora and Vernucosisporites and cingulizonate Densosporites and Kraueselisporites.

The 35 taxa listed on fig. 2 are nearly all also known in western Europe and many are guide-species of the detailed palynozonations most often in use in this area. On fig. 3 are shown the main biohorizons (first and/or last occurences) used by Higgs et al. 1988.

Amongst the few spores recognized in the lowermost sample (core $55: 2485,00 / 2483,80 \mathrm{~m}$ ) are Rugospora radiata, Retispora lepidophyta and Hymenozonotriletes explanatus. The latter occurs higher but coexists with the two others in the palynozonation of western Europe (Streel et al. 1987). This first occurence marks the base of the LE (R. lepidophyta-H. explanatus) Biozone. The absence of Verrucosisporites nitidus, a characteristic miospore of the next younger biozone, allows us to re- 
7

\begin{tabular}{|c|c|c|c|c|}
\hline$\unlhd$ & $\tilde{x}$ & $x$ & 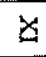 & 츰 \\
\hline
\end{tabular}
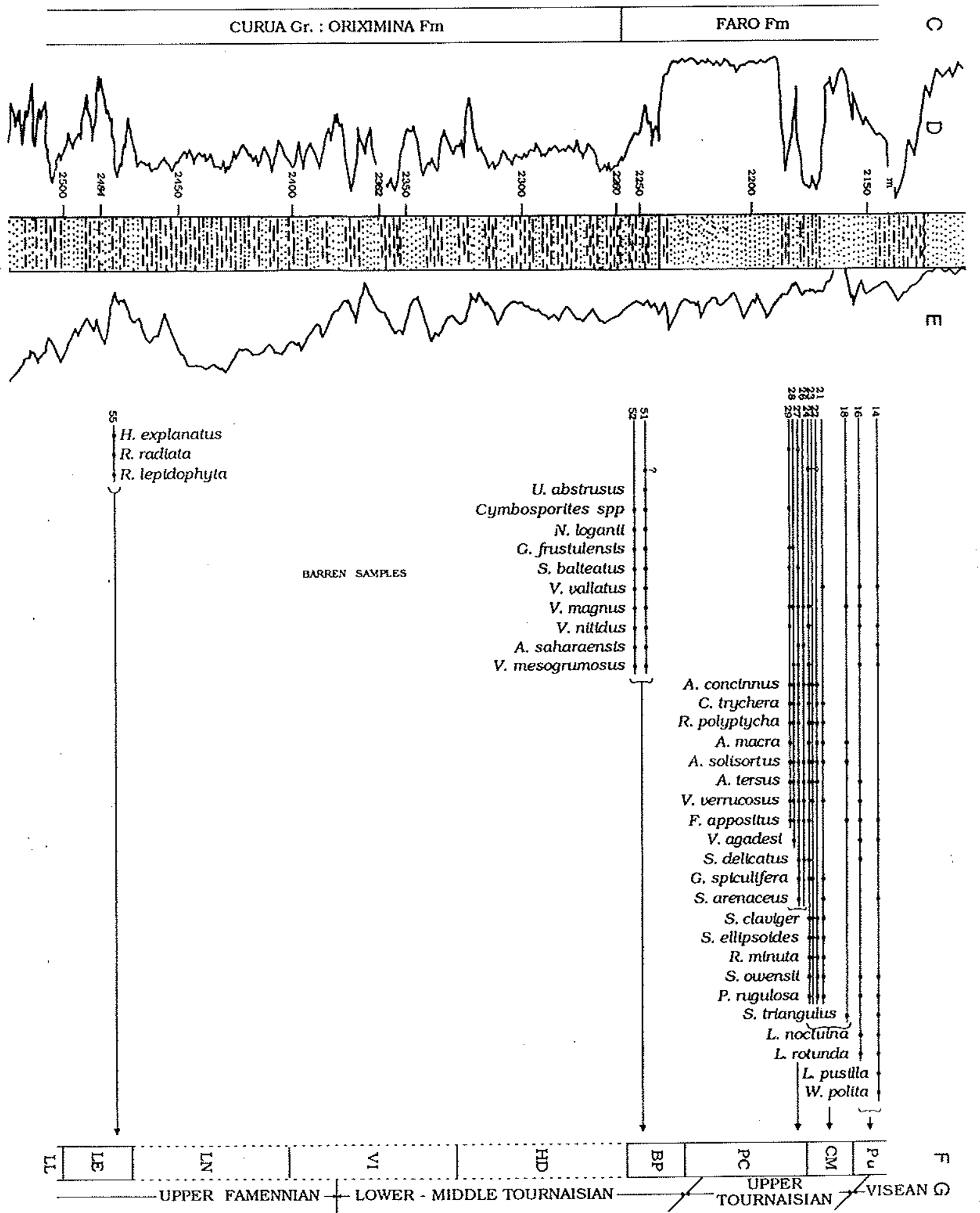

Figure 2 - Miospore distribution in 2-LF-1-AM borehole and comparison with Western European zonation. Key : A, biostratigraphy after Daemon 1974. B, chronostratigraphy after Daemon 1974. C, lithostratigraphy after Caputo 1984 . D.E, from the left to the right, gamma ray, lithology and resistivity. F, biostratigraphy after Higgs et al. 1988. G, chronostratigraphy after Higgs et al. 1988.

Répartilion des miospores dans le sondage 2.LP.1-AM el comparaison avec la zonation de l'Burope de l'Ouest. 
strict this lowermost sample to the LE Biozone which corresponds, in the Sauerland (FRG), to the conodont based Lower to Middle praesulcata Zone of latest Famennian age (Higgs \& Streel 1984).

The younger samples can be compared to the Lower Carboniferous of Ireland where, in contrast with the Sauerland, the sediments belong to a platform system devoid of the conodonts characterizing the Standard

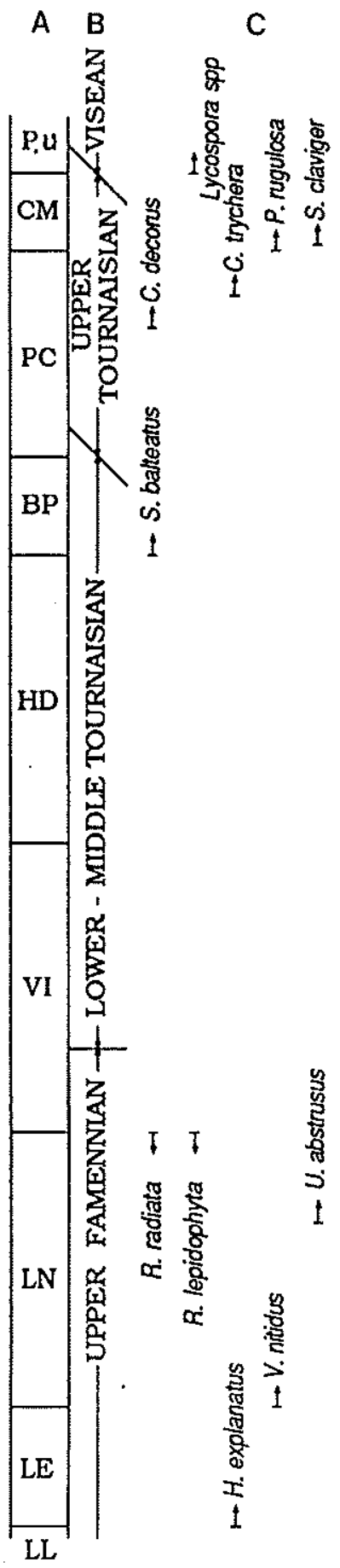

Figure 3 - Main biohorizons of the British Isles palynozonation after Higgs et al. 1988. Key: A, biostratigraphy. B, chronostratigraphy. $\mathrm{C}$, main characteristic miospores.

Principauts bioborizons de la palynozonation des lles Britamigues d'après Higgs et at. 1988.
Lower Carboniferous Zonation (Higgs et al. 1988). Therefore dating is less accurate.

Amongst the more abundant and diversified miospores found in the next two productive samples (cores 52 and 51 at $2256,80 / 2252,00 \mathrm{~m}$ ) is Spelaeotriletes balteatus whose first occurrence in Western Europe delineates the base of the BP ( $S$. balteatus- $R$. polyptycha) Biozone. The absence of Spelaeotriletes pretiosus, a characteristic miospore of the next younger Biozone, allows us to restrict these two samples to the BP Biozone of Middle Tournaisian age. We note that Higgs et al. 1988, on their fig. 3, mention the first occurrence of Vallatisporites vallatus at the base of the BP Biozone, but indicate page 80 the presence of this species below (VI Biozone). Moreover, Van Veen 1981, on his fig. 2, notes $V$. vallatus in the uppermost part of his Retispora lepidohyta Assemblage Zone in Ireland.

The next stratigraphic sequence bearing miospores is thicker (cores 29 to 14, between 2190,00 and 2149,70 $\mathrm{m})$. Most of the miospores here were not identified below. (Note that more than $60 \mathrm{~m}$ of barren sediments occur between cores 51 and 29).

The first occurrence of Schopfites claviger in core 24 (at $2180,20 / 2180,10 \mathrm{~m}$ ) indicates the base of the CM (S. claviger-A. macra) Biozone and the first occurrence of $L y c o-$ spora spp. in core 16 (at $2159,90 / 2156,60 \mathrm{~m}$ ), the base of the Pu (L. pusilla) Biozone. Below core 24 (cores 29 to 25), Crassispora trychera, a characteristic taxon of the upper part of the older PC Biozone, is nearly always present. Therefore, this thick stratigraphic sequence (cores 29 to 14) has to be referred to the interval ranging from the upper part of the PC Biozone into the lower part of the $\mathrm{Pu}$ Biozone, covering most of the Upper Tournaisian and part of the Lower Visean.

\section{COMPARISON WITH FORMER BIOSTRATIGRAPHY IN THE SAME BOREHOLE}

Comparison with Daemon's 1974, fig. 2 palynostratigraphy gives the following results : zone XII (Daemon) includes Biozones $\mathrm{Pu}, \mathrm{CM}$ and upper $\mathrm{PC}$; zone XI (Daemon) includes Biozones BP ; zone VII (Daemon) includes Biozone LE. The geochronological interpretation given by Daemon 1974, although less accurate, is entirely confirmed by our study. Compared bio-, litho- and chronostratigraphic data will be discussed in another paper.

\section{GONDWANAN ASPECT OF THE MIOSPORE ASSEMBLAGE}

A few species only known so far from the Gondwana have been identified : Arastrisporites saharaensis, Valla- 
tisporites agadesi, Spelaeotriletes owensii, Granulatisporites frustulensis and Grandispora spiculifera. The first three species were described from North Africa (Loboziak \& Alpern 1978 ; Loboziak et al. 1986), the last two ones from Australia (Balme \& Hassel 1962; Playford 1976). They are rare and alone to represent the Gondwanan aspect of these asemblages. Consequently, the difference between the Gondwanan and Euramerican miospore assemblages during the Lower Carboniferous is not conspicuous.

\section{CONCLUSION}

Recent research on miospores from the Ponta Grossa Formation in the southern part of Mato Grosso State, Paraná Basin (Burjack et al. 1988), has already shown that the middle Devonian-Frasnian miospore zonation of southern Euramerica (mainly the Ardenne-Rhenish basins, Streel et al. 1987) could be applied to the Brazilian basins.

We now demonstrate that this is also true for the Lower Carboniferous when compared to the Irish zonation of Higgs et al. 1988. However a few miospores identified in Brazil are not known from western Europe. But it is apparent that the distinction in the Lower Carboniferous Gondwanan and Euramerican palynofloras is less marked than in the Upper Carboniferous.

\section{SPECIES LISTED}

Anapiculatisporites concinums Purrord, 1962

Anaptalatisporites terstis PLATORD, 1963

aralrisporiles sabaraensis logozu, CLYToN \& OWES, 1986

Auroraspora macta SuLLive, 1968

Auroraspora solksorthis HoTMEISTER, STAPLLX \& MLLLO, 1955

Crassispora frycbera Neves \& lawidides, 1974

Poveosporites appositus PuYroRD, 1971

Gramilispora spiculifera Puitord, 1976

Granulatisporiles frishlensis (BuLEE \& 1LLNEL) PUYFORD, 1971

Hymonozonotriletes explamatus (LUBER) KeDo, 1963

Lycospora nocluina BuTERAYREH \& WHLLUS, 1958

Lycospora pusilla (IBR+RLY) SOMERS, 1972

Lycospora rohuma (BHLRWWA) SOMEKs, 1972

Neoraistrickia loganil (BUTtERHORTH \& SPLWER) TURAU, 1978

Relispora lepilopbyia (KeDo) Purrond, 1976

Rigospora minuta Neves \& Iaswioss, 1974

Rugaspora polyphycha Neves \& lousatDes, 1974

Rigaspora radiata (Juschio) Bisher, 1985

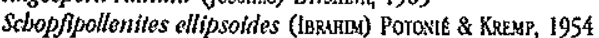

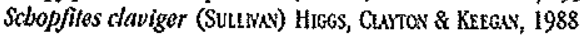

Schopfiles delicahis (Higcs) Higos, Curtow \& KeEgtv, 1988

Spelaeotriletes arenaceus Neyes \& OveNs, 1966

Spelaeorriletes balteatius (PLATORD) HiGos, 1975

Spelneorileles owensii LoBcens \& ALPER, 1978

Spelaeofrileles iriangulus Neves \& OWENS, 1966

Umbonalisporites abstrusts (PIATTORD) Custos, 1971

Vallatisporiles agadesi LoBQZLA \& ALPER, 1978

Vallatisporites vallatus HuQQUER,RD, 1957

Yallatisporties verricastis HicoUEBARD, 1957

Velamisporiles magmis (HUGHES \& PLATrORD) PurroRD, 1971
Verricosisporites mesogrtmosts (KeD) Bwstev, 1985

Verrucosisporiles nitkitus (Numosis) PLutoRo, 1964

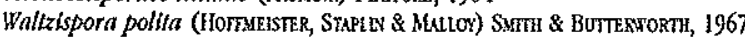

Acknowledgements - The authors thank Petrobas for providing the core material and giving the authorization to publish.

\section{BIBLIOGRAPHY}

BALME B.E. \& HaSsel C.W. 1962 - Upper Devonian spores from the Canning Basin, Western Australia. Micropaleontology, 8, 1 : 1-28.

BURJACK M.I.A., LOBOZIAK S. \& STREEL M. 1987 Quelques données nouvelles sur les miospores dévoniennes du bassin du Paraná (Brésil). Sci. Géol. Bull., 40, $4: 381-391$.

CAPUTO M.V. 1984 - Stratigraphy, tectonics, paleoclimatology and paleography of northern basins of Brazil. Ph. D. Thesis Univ. of California : 582 p. (unplublished).

DAEMON R.F. 1974 - Palinomorfos-Guias do Devoniano Superior e Carbonifero Inferior das Bacias do Amazonas e Parnaiba. An. Acad. Brasil Cienc., 46, $3 / 4: 549-587$.

Higgs K., Clayton G. \& KeEgan J.B. 1988 - Stratigraphic and Systematic Palynology of the Tournaisian Rocks of Ireland. Geol. Surv. Ireland, $7: 93$ p.

HIGgS K. \& STREEL M. 1984 - Spore stratigraphy at the Devonian Carboniferous boundary in the northern "Rheinisches Schiefergebirge", Germany. Cour. Forsch. Inst. Senckenberg, 67 : 157-179.

LOBOZIAK S. \& ALPERN B. 1978 - Le bassin houiller d'Agadès (Niger) : les microspores. Palinologia, 1 : 55-67.

LoBOZIAK S., Clayton G. \& OWENS B. 1986 - Arastrisporites saharaensis $\mathrm{sp}$. nov. : a characteristic Lower Carboniferous miospore species of North Africa. Geobios, 19, 4 : 386-391.

LoboziaK S., STREel M. \& BURJACK M.I.A. 1988 Miospores du Dévonien moyen et supérieur du bassin du Paraná, Brésil : Systématique et Stratigraphie. Sci. Geol. Bull., 41, 3-4 : 351-377.

PLAYFORD G. 1976 - Plant microfossils from the Upper Devonian and Lower Carboniferous of the Canning Basin, Western Australia. Palaeontographica, B, 158, 1-4:1-71.

StREel M., HiggS K., LoboziaK S., Riegel W. \& STEEMANS P. 1987 - Spore stratigraphy and correlation with faunas and floras in the type marine Devonian of the Ardenne-Rhenish regions. Rev. Palaeobot. Palynol., 50 : 211-229.

VAN VEEN P.M. 1981 - Aspects of late Devonian and early Carboniferous palynology of Southern Ireland. The change in composition of palynological assemblages at the Devonian-Carboniferous boundary. Rev. Palaeobot. Palynol., 34 : 67-97. 


\section{PLATE 1}

All palynological material is housed in the collections of the Laboratory of Palaeobotany and Palaeopalynology, University of Liège. Illustrated specimens magnification $x 500$. Les préparations palynologiques sont conservées dans les collections du Laboratoire de Paléobotanique et Paléopalynologie de l'Université de Liège. Grossissement des individus illustrés $x$ 500.

Fig. 1 - Retispora lepidophyta (KEDO) PLAYFORD, 1976. Slide 24(1) : N352, Fig. 2 - Rugospora radiata (JuschKo) BYYSCHEVA, 1985.

Fig. 3 - Rugospora minuta NEVES \& IOANNIDES, 1974. Slide 23(1) : U36 2 .

Fig. 4 - Rugospora polyptycha NeVES \& IOANNIDES, 1974. Slide 21(1) : L2 7 .

Fig. 5 - Schopfites claviger (SullivaN) Higgs, Clayton \& KeEGAN, 1988. Slide 24(1) : P28 2 .

Fig. 6 - Spelaeotriletes balteatus (PLAYFORD) HigGS, 1975. Slide 51(3) : R37 ${ }^{3}$.

Fig. 7 - Grandispora spiculifera PLAYFORD, 1976. Slide 21(2): W28 2 .

Fig. 8 - Foveosporites appositus PLAYFORD, 1971. Slide 14(1) : M25.

Fig. 9 - Prolycospora nigulosa (BUTTERWORTH \& SPINNER) TURNAU, 1978. Slide 14(1) : $\mathrm{G} 29^{3}$.

Fig. 10 - Lycospora pusilla (IBRAHIM) SOMERs, 1972. Slide 14(1) : Y303.

Fig. 11 - Lycospora rotunda (BHARADWAJ) SOMERS, 1972. Slide 14(1): M29 $9^{3}$.

Fig. 12 - Auroraspora solisortus HOFFMEISTER, STAPLIN \& MALLOY, 1955. Slide 21(1) : T38 4

Fig. 13 - Alyroraspora macra SULLIVAN, 1968. Slide 18(1) : $\$ 19^{3}$.

Fig. 14 - Vallatisporites vallatus HACQUEBARD, 1957. Slide 21(1) : G322.

Fig. 15 - Vallatisporites vernucosus HACQUEBARD, 1957. Slide 21(1) : Q372.

Fig. 16 - Waltzispora polita (HofFMEISTER, STAPLIN \& MALlOY) SMTTH \& BUTTERWORTH, 1967. Slide 14(1) : K42

Fig. 17 - Schopfipollenites ellipsoides (IBRAHIM) POTONIÉ \& KREMP, 1954. Slide 21(1) : E31.

Fig. 18 - Crassispora trychera NEVES \& IOANNIDES, 1974. Slide 29(1) : L381.

Fig. 19 - Anapiculatisporites concinnus PlAYFORD, 1962. Slide 28(1) : U38 ${ }^{1}$

Fig. 20 - Vernicosisporites nitidus (NAUMOVA) PLAYFORD, 1964. Slide 16(1) : V383.

Fig. 21 - Aratrisporites saharaensis LOBOZIAK, CLAYTON \& OWENS, 1986. Slide 51(3) : E43.

Fig. 22 - Vallatisporites agadesi LOBOZIAK \& ALPERN, 1978. Slide 14(1): $\mathrm{J}^{2} 9^{2}$.

Fig. 23 - Spelaeotiletes arenaceus NEVES \& OWENS, 1966. Slide 14(1) : J27.

Fig. 24 - Spelaeotriletes triangulus NEves \& OWENS, 1966. Slide 14(1) : J36.

Fig. 25 - Spelaeotriletes owensii LOBOZIAK \& ALPERN, 1978. Slide 14(1) : Y401. 
Geobios

$\mathrm{n}^{2} 24$,fasc. 1
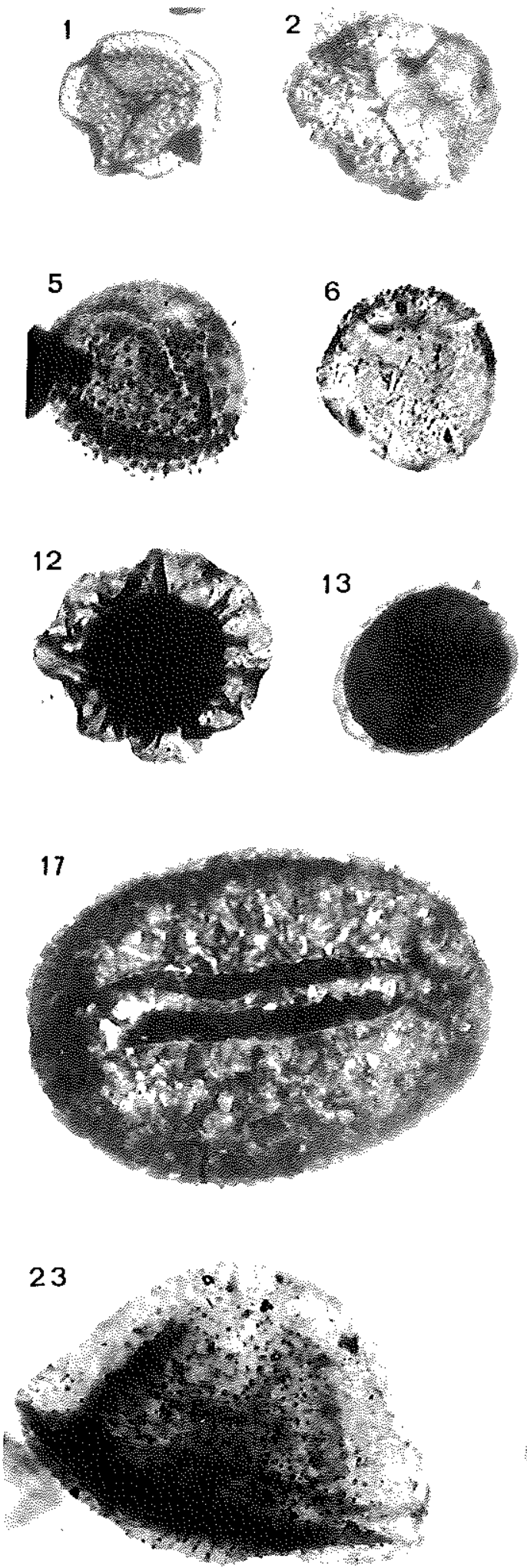

S. Loboziak, M. Streel, M.V. Caputo \& J.H.G. de Melo
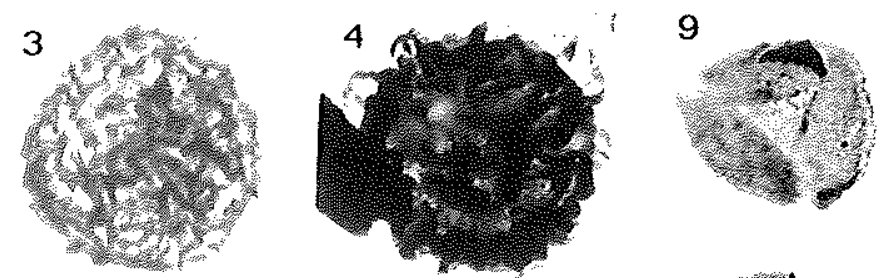

10
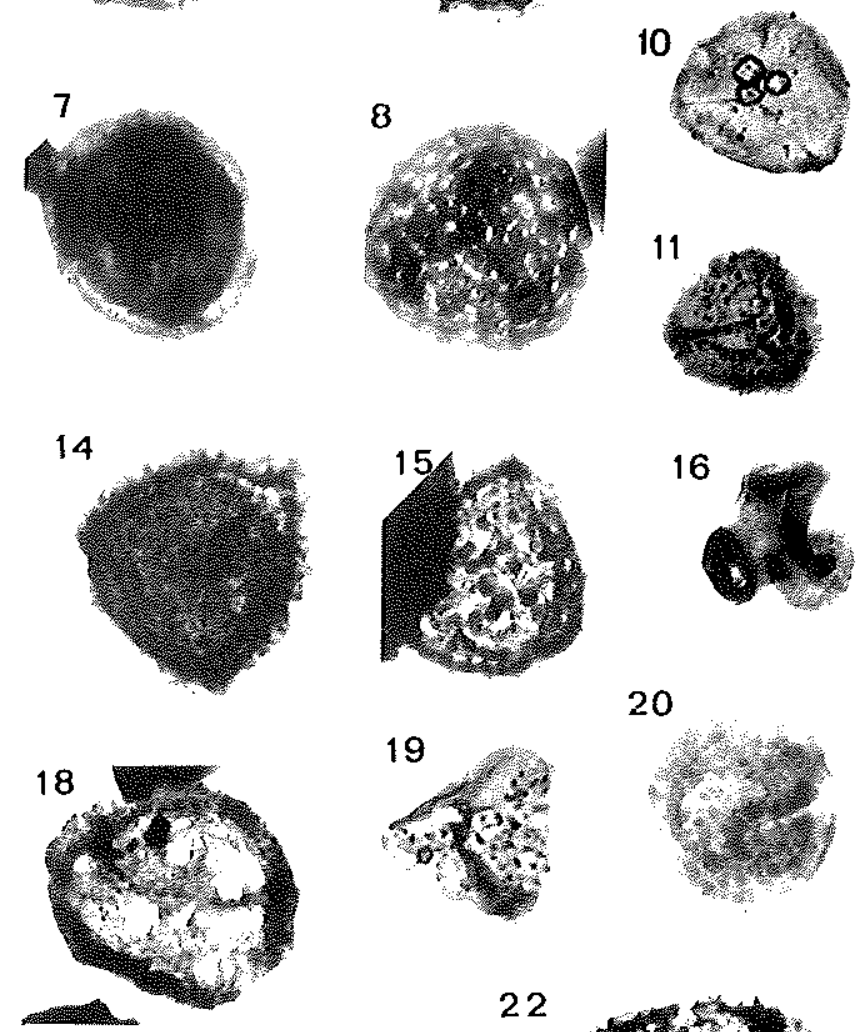

20
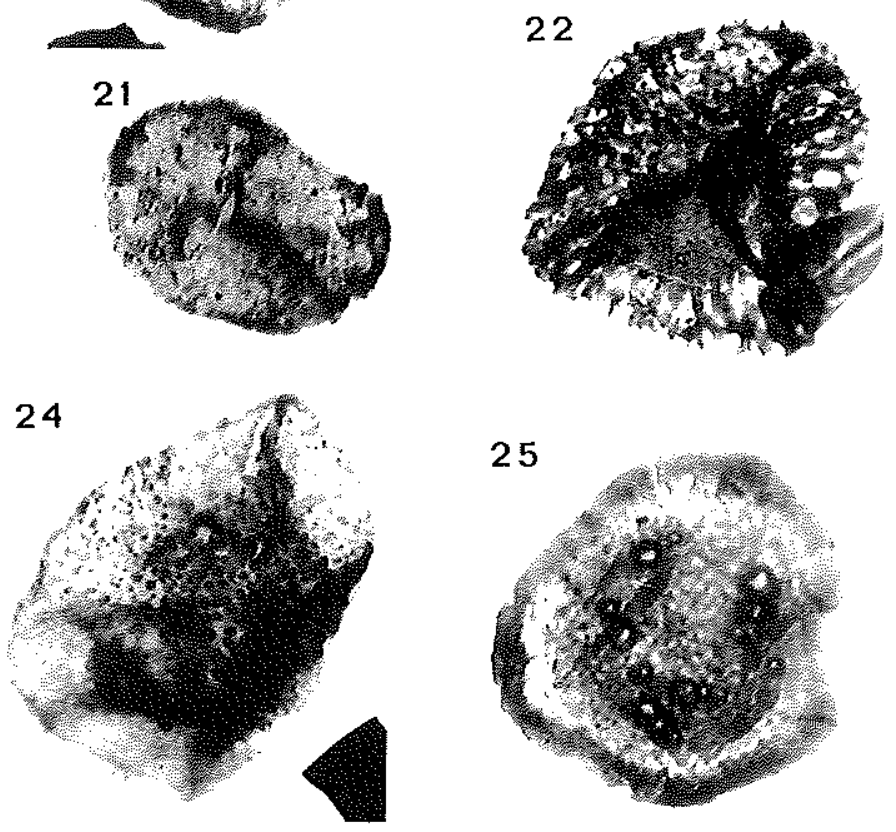
